\title{
Development and Validation of RP-HPLC Method for Simultaneous Qualitative and Quantitative Estimation of Curcumin and Quercetin in Bulk Mixture
}

\author{
Nayana Patil*, Hitendra Mahajan \\ Department of Pharmaceutics, R C Patel Institute of Pharmaceutical Education and Research, Shirpur, Dhule, Maharashtra, INDIA.
}

\begin{abstract}
Objectives: To design a definite, new and explicit reverse phase high performance liquid chromatographic (RP-HPLC) method for simultaneous estimation of quantitative and qualitative curcumin and quercetin in bulk mixture. As per guidelines of International conference on harmonization (ICH) method was validated. Materials and Methods: In this study, reverse phase analysis was used to do the analysis Younglin- ACME 9000, $C_{18}$ $(250 \times 4.6 \mathrm{~mm}$ i.d) solvent system methanol and $0.05 \%$ orthophosphoric acid as mobile phase in proportion of $80: 20 \mathrm{v} / \mathrm{v}$ was used. The flow rate at constant rate $0.7 \mathrm{ml} / \mathrm{min}$. The absorbance of the eluted sample was analyzed by use of UV Visible detector at $254 \mathrm{~nm}$. Results: The proposed improved methodology takes $5.25 \mathrm{~min}$ to elute curcumin and $8.78 \mathrm{~min}$ to elute quercetin. The system suitability parameters were studied for the developed method and were found to be within the acceptable limits. The LOQ and LOD of curcumin was reported to be 0.041 and $0.081 \mathrm{~g} / \mathrm{ml}$, respectively, while quercetins were 0.0048 and $0.039 \mathrm{~g} / \mathrm{ml}$. Conclusion: The designed methodology validated as per the $\mathrm{ICH}$ guidelines for its linearity, precision, specificity, sensitivity, accuracy, raggedness, robustness, LOD, and LOQ. The results of the preceding observations show that the procedure is effective in both qualitative and quantitative analyses of the markers in the mixture.
\end{abstract}

Key words: RP-HPLC, Curcumin, Quercetin, Validation, Qualitative, Quantitative.

\section{INTRODUCTION}

Curcumin is a polyphenolic compound obtained from turmeric (Curcuma longa, family Zingiberaceae) and has long been known for its medicinal effects. ${ }^{1-3}$ It has attracted medical and scientific attention because it deals with the management of oxidative and inflammatory disorders like cancer, metabolic syndrome and arthritis. ${ }^{3-7}$ Its antioxidant and anti-inflammatory qualities are responsible for the majority of these benefits. Curcumin consumption on its own does not result in allied health advantages due to its low blood levels, because of inadequate absorption, rapid metabolism, and rapid excretion. Bioavailability can be boosted by a variety of ingredients. Piperine, for example, is the main active ingredient in black pepper and has been known to improve bioavailability by $2000 \%$ when coupled with curcumin. Curcumin, in combination with boosting mediators, has a number of health effects. ${ }^{8-15}$

Quercetin is most significant bioflavonoids existing in about twenty plants and which is recognized due to its antihypertensive, antiinflammatory, vasodilator properties, antiobesity and anticholestermic actions. ${ }^{16-26}$ The word "quercetin" comes from the Latin word "quercetum," which meaning "oak forest, belongs to the flavanol class of compounds that cannot be synthesized in the human body. It is yellow in color and is poorly in hot water soluble, alcohol soluble in a moderate amount and lipids and insoluble in cold water. ${ }^{27-31}$ The chemical name of quercetin is 2-(3,4-dihydroxyphenyl)-3,5,7-
Submission Date: 24-08-2021; Revision Date: 05-10-2021; Accepted Date: 09-11-2021.

DOI: 10.5530/ijper.56.1.29 Correspondence: Mr. Nayana Devidas Patil Research Scholar, R C Patel Institute of Pharmaceutical Education and Research Shirpur, Dist Dhule-425405, Maharashtra, INDIA.

E-mail: sulkan.21@rediffmail.com 


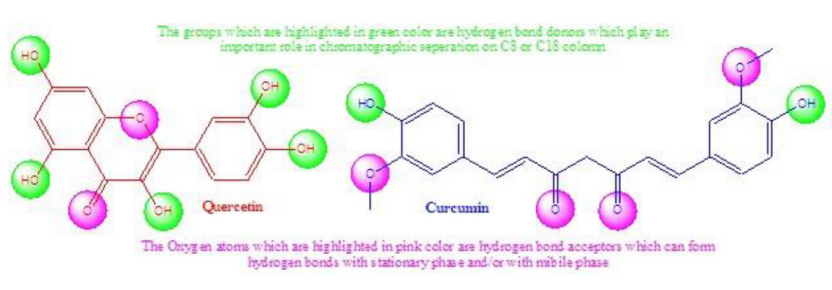

Figure 1: The structures of Curcumin and Quercetin with hydrogen bond donors and acceptors group highlighted in green and pink color respectively.

trihydroxychromen-4-one. The structures of curcumin and quercetin are represented in Figure 1.

Both phyto constituents rarely found in single plant together but numerous nutraceutical formulation contains combination of these compounds. There have been many methods are reported for the analysis of these drugs in bulk majorly on UV Visible spectroscopy. ${ }^{32-34}$ HPTLC (high performance thin layer chromatography) and HPLC (high performance liquid chromatography) are two types of chromatography are commonly used methods for quantitative estimation of the curcumin and quercetin. ${ }^{34-45}$ There is no any analytical method was reported previously for simultaneous estimation of curcumin and quercetin. In present work, we have developed simple, precise, optimized and validated the RP-HPLC method for simultaneous quantification of curcumin and quercetin in bulk. The approach was validated according to the International Conference on Harmonization's requirements $(\mathrm{ICH})$. This latest validated process will be extended to industry and academics.

\section{MATERIALS AND METHODS}

\section{Chemical and Reagents}

Curcumin (99\%) was obtained as a gift sample from Sun Pure Extract in New Delhi, while quercetin was obtained from Otto Chemicals in Marine Lines, Mumbai, and HPLC grade methanol, water, and orthophoshopric acid were obtained from Avi Chemicals in Mumbai.

\section{Instruments}

A HPLC system consisting of Younglin (S.K) Gradient System, Column $\mathrm{C}_{18}(250 \times \mathrm{x} 4.6 \mathrm{~mm}$ i.d), and size packing of $5 \mu \mathrm{m}$, detector UV $730 \mathrm{D}$, software-Autochro-3000, and pump SP930 D were used for the method development, data analysis, and interpretation.

\section{Selection of Wavelength}

Adequate wavelength for chromatographic separation was calculated by recording UV spectrum in the range of 200-400 $\mathrm{nm}$ for curcumin and quercetin. The UV overlain spectra of these two markers revealed that medications absorbed at $254 \mathrm{~nm}$ and $256 \mathrm{~nm}$, respectively, although $254 \mathrm{~nm}$ was chosen as the measuring wavelength for the HPLC study since it provided greater resolution. The overlain UV spectra of both the drugs is represented in Figure 2.

\section{Chromatographic Parameter}

Reverse phase on a $\mathrm{C}_{18}$ column $(250 \times 4.6 \mathrm{~mm}$ i.d, particle size $5 \mu \mathrm{m}$ ) was used to develop the process. After running many trials, a solvent system methanol: $0.05 \%$ orthophosphoric acid (80:20) with $0.7 \mathrm{ml} / \mathrm{min}$ flow rate and $20 \mu \mathrm{l}$ sample size had provided better chromatographic separation with good resolution. The analysis was performed at $254 \mathrm{~nm}$ wavelength and at ambient temperature.

\section{Preparation of Standard Stock Solutions}

$1 \mathrm{mg}$ of pure medicine was dissolved in $10 \mathrm{ml}$ of methanol to make stock solutions of curcumin $(0.1 \mathrm{mg} / \mathrm{ml})$ and quercetin $(0.1 \mathrm{mg} / \mathrm{ml})$.

\section{Sample Preparation}

Specific aliquots from stock solutions were used to make the sample solutions. To make $10 \mathrm{~g} / \mathrm{ml}$ of sample solution, $0.1 \mathrm{ml}$ of each stock solution was pipetted out and diluted separately with methanol up to $10 \mathrm{ml}$.

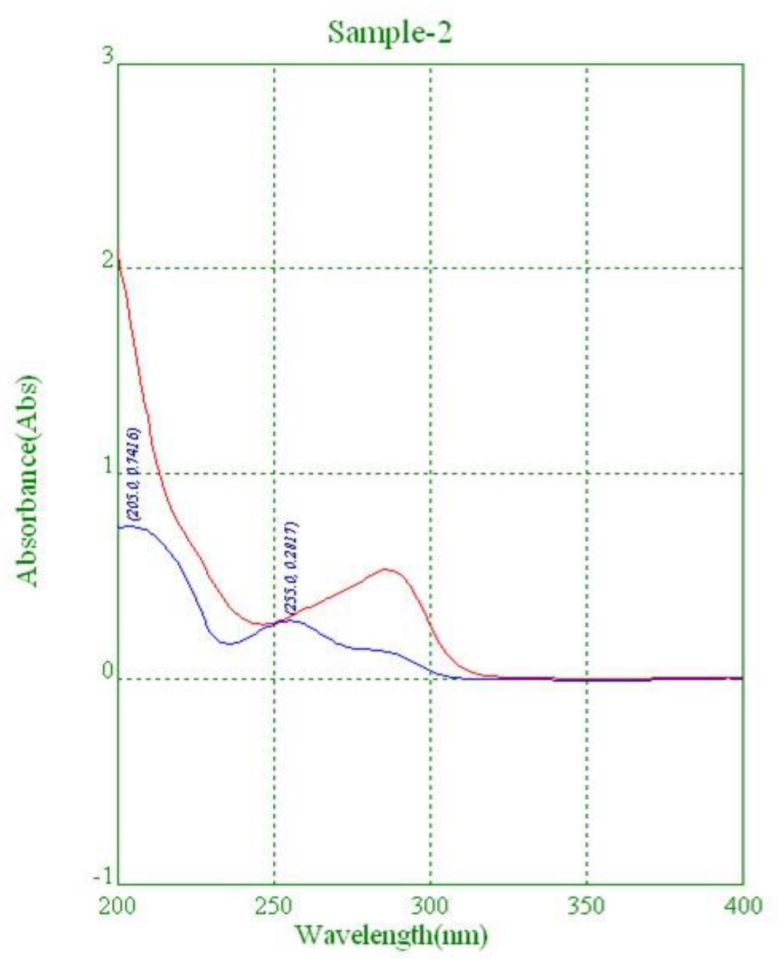

Figure 2: The isobestic point of both the drugs in UV Visible Spectroscopy at $254 \mathrm{~nm}$. 
Likewise, the remaining sample solutions were made in the $10 \mathrm{~g} / \mathrm{ml}$ to $50 \mathrm{~g} / \mathrm{ml}$ range.

\section{Analytical method validations}

The developed RP-HPLC method of curcumin and quercetin was validated as per the ICH guidelines. The method was tested with linearity, precision, specificity, sensitivity, accuracy, raggedness, robustness, limit of quantification (LOQ), and limit of detection (LOD).

\section{Application of developed analytical method Preparation of plasma samples}

To $100 \mu \mathrm{l}$ of curcumin standard solution and $100 \mu \mathrm{l}$ of quercetin standard solution, $100 \mu \mathrm{l}$ of plasma sample, were spiked and added extraction solvent $2 \mathrm{~mL}$ of acetonitrile was added and vortexed mixture for $20 \mathrm{~min}$. This sample was ultracentrifuged at $10,000 \mathrm{rpm}$ for 10 min. The supernatant layer was collected and $20 \mu \mathrm{l}$ was analyzed by HPLC system. The whole procedure was carried out at room temperature.

\section{Estimation of Pharmacokinetic method}

Suspension of both compounds in sterile water for injection was administrated to mice $(n=3)$ intravenously and blood sample was collected from retro-orbital vein into heparinized bulb at different time intervals 5, 10, 30, 45, 60, 120, 240, 480, 1440 mins to $24 \mathrm{hr}$. Heparinized blood samples were centrifuge at $5000 \mathrm{rpm}$ for $15 \mathrm{~min}$ to obtain plasma same was stored at $-80^{\circ} \mathrm{C}$ till further analysis. Pharmacokinetic parameters were calculated by Kinetica software. The highest plasma drug concentration $\left(\mathrm{C}_{\max }\right)$ and time of highest plasma drug concentration $\left(t_{\max }\right)$ were determined from plasma concentration vs time curve. Area under the curve $\left(\mathrm{ACU}_{0-t}\right)$ for curcumin and quercetin plasma concentration $\mathrm{v} / \mathrm{s}$ time zero to $24 \mathrm{~h}$ was also calculated.

\section{RESULTS AND DISCUSSION}

The RP-HPLC method was designed with the goal of estimating curcumin and quercetin in bulk, and system suitability criteria such as peak resolution factor, tailing factor, number of theoretical plates, runtime, and cost effectiveness were considered.

Curcumin elution took 5.25 min while quercetin took 8.78 min using the developed improved procedure. The produced chromatogram of curcumin and quercetin is shown in Figure 3. The system suitability characteristics are shown in Table 1. Curcumin and quercetin were discovered to have 3255 and 4266

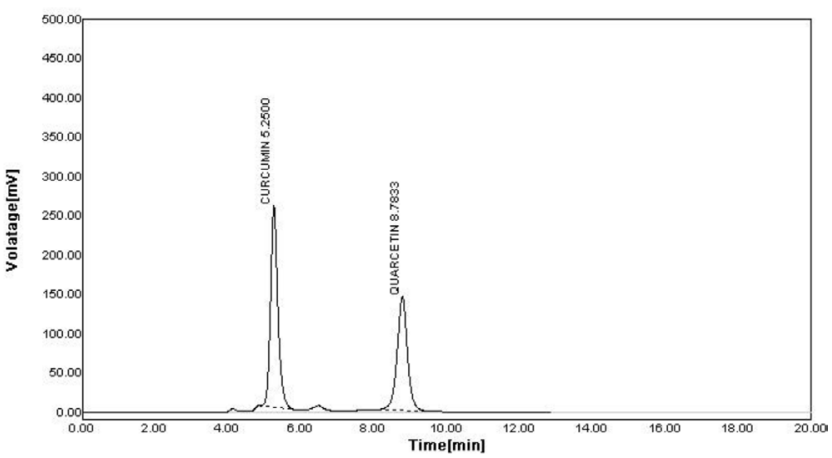

Figure 3: The developed chromatogram of the optimized method for curcumin and quercetin.

Table 1: The system suitability parameters and results.

\begin{tabular}{|c|c|c|c|}
\hline Parameters & $\begin{array}{c}\text { Acceptance } \\
\text { limits }\end{array}$ & Curcumin & Quercetin \\
\hline $\begin{array}{c}\text { Retention time } \\
\text { (min) }\end{array}$ & -- & 5.25 & 8.78 \\
\hline Resolution factor & Not less than 2 & 0.00 & 6.62 \\
\hline $\begin{array}{c}\text { Number of } \\
\text { theoretical plate }\end{array}$ & $\begin{array}{c}\text { Not less than } \\
2000\end{array}$ & 3255 & 4266 \\
\hline Tailing factor & $\begin{array}{c}\text { Not more } \\
\text { than 2 }\end{array}$ & 1.23 & 0.95 \\
\hline
\end{tabular}

theoretical plates, respectively. Each trial took $15 \mathrm{~min}$ to complete.

\section{Method Validation Specificity}

The developed chromatogram of the optimized method for curcumin and quercetin for standard drug solutions, shown in Figure 3, reveals that the peaks obtained in the standard solutions at working concentrations are only due to the drugs, as the blank has no peak at the retention time of curcumin and quercetin. As a result, it is possible to conclude that the established approach is specific.

\section{Linearity}

The detection wavelength was identified by preparing $10 \mathrm{ppm}$ solution of curcumin and quercetin in methanol. The study was carried out at $254 \mathrm{~nm}$ for both the drugs which had shown better response. The linearity of the curve of peak area versus curcumin and quercetin concentrations $(10-50 \mathrm{~g} / \mathrm{ml})$ was determined. The correlation coefficients $\left(R^{2}\right)$ for each drug were greater than 0.99 , which passed the technique validation acceptance criteria, indicating that the method is linear. The calibration curves of curcumin and quercetin 


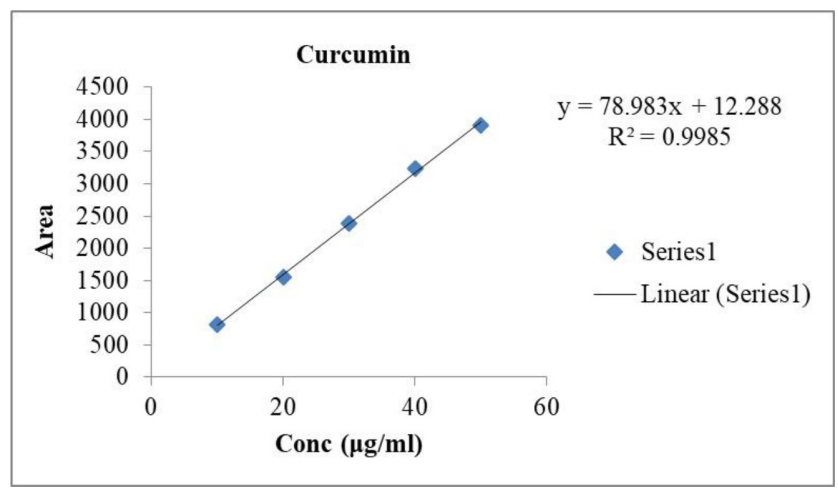

Figure 4: The calibration curve of curcumin at $254 \mathrm{~nm}$ (10- $50 \mu \mathrm{g} / \mathrm{ml})$.

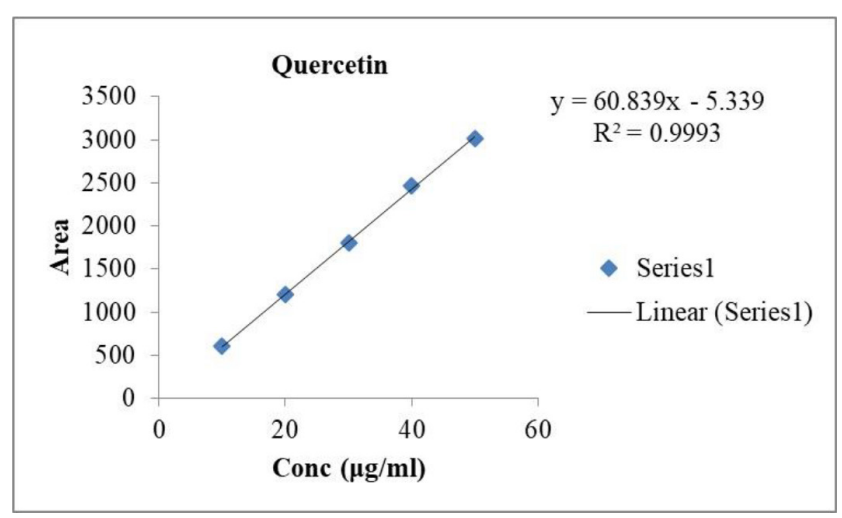

Figure 5: The calibration curve of quercetin at $254 \mathrm{~nm}$ (10- $50 \mu \mathrm{g} / \mathrm{ml})$.

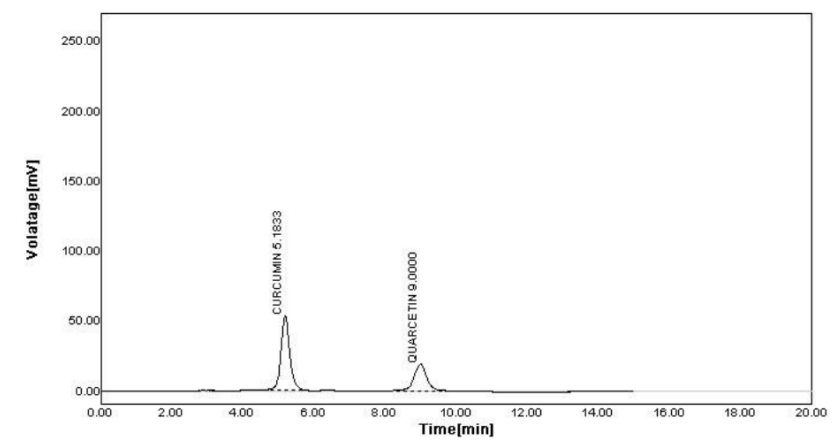

Figure 6: The chromatogram of curcumin and quercetin in bulk at $10 \mu \mathrm{g} / \mathrm{ml}$.

are represented in Figures 4 and 5 respectively. These Figures also represents the regression equations.

\section{Precision}

System precision, method precision, intraday precision, and interday precision were all investigated in the precision research. In system precision, the same concentration is injected six times, while in method precision, the same concentration is injected in three different vials. Intraday precision $(10,30,50 \mathrm{~g} / \mathrm{ml})$ of curcumin and quercetin were tested to see if they were repeatable, as well as interday variation for intermediate precision $(10,30,50 \mathrm{~g} / \mathrm{ml})$ under the same conditions. The relative standard deviation (RSD) and percentage standard deviation (SD) were calculated and found to be within the allowed ranges. The chromatograms obtained as interday precision for 10,30 and $50 \mu \mathrm{g} / \mathrm{ml}$

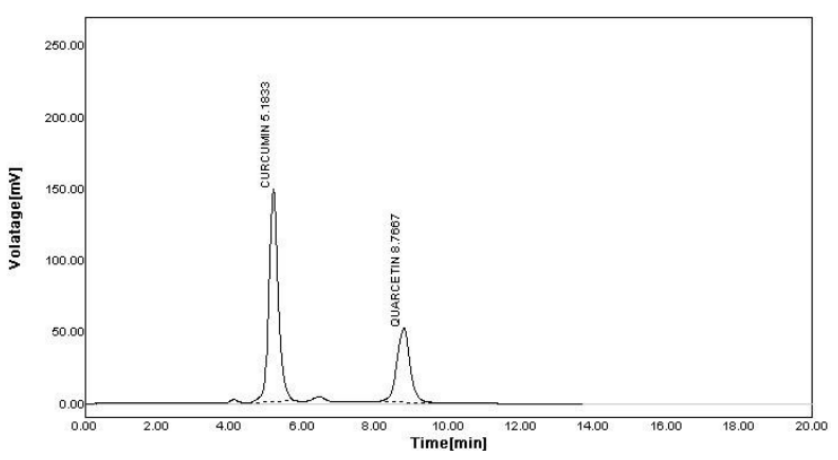

Figure 7: The chromatogram of curcumin and quercetin in bulk at $30 \mu \mathrm{g} / \mathrm{m}$.

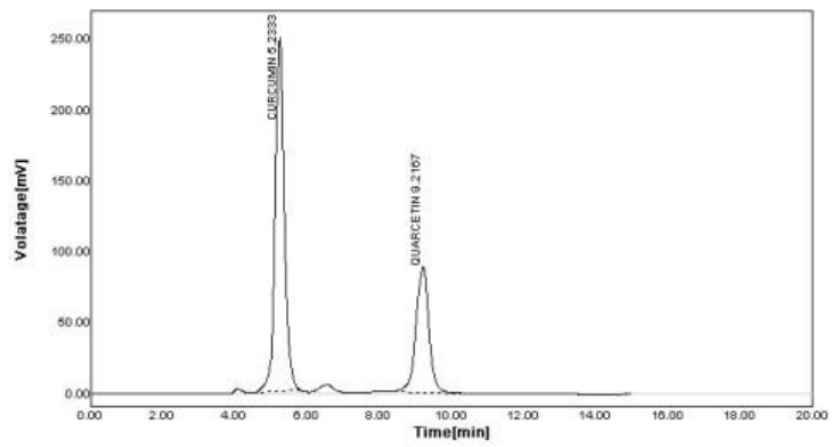

Figure 8: The chromatogram of curcumin and quercetin in bulk at $50 \mu \mathrm{g} / \mathrm{ml}$.

\begin{tabular}{|c|c|c|}
\hline \multicolumn{2}{|c|}{ Table 2: The precision results of optimized method. } \\
Compound & $\begin{array}{c}\text { Repeatability }(n=6) \\
\text { Mean }(\boldsymbol{\mu g} / \mathrm{ml}) \pm \text { Standard } \\
\text { Deviation }\end{array}$ & RSD (\%) \\
\hline Curcumin & $50.39 \pm 0.43$ & 0.86 \\
\hline Quercetin & $50.48 \pm 0.40$ & 0.78 \\
\hline & $\begin{array}{c}\text { Intermediate precision } \\
(n=6)\end{array}$ & \\
\hline Curcumin & $30.14 \pm 3.99$ & 0.17 \\
\hline Quercetin & $29.99 \pm 1.16$ & 0.06 \\
\hline & Reproducibility $(n=10)$ & \\
\hline Curcumin & $49.46 \pm 1.71$ & 0.04 \\
\hline Quercetin & $49.39 \pm 1.14$ & 0.04 \\
\hline
\end{tabular}


are represented in Figures 6, 7, and 8 respectively. The precision data of the optimized method is represented in Table 2.

\section{Accuracy}

Recovery studies were used to determine accuracy, with the percent mean recovery of each chemical in the bulk measured at three distinct levels (80 percent, 100 percent and 120 percent). As stated in Table 3 , the percent mean recovery was determined. The approved mean recovery limits were 98-102 percent, and all of the observed data fell within this range, indicating good recovery values and confirming the accuracy of the established approach.

\section{Sensitivity}

It is limit for reliable method to detect minimum level of analyte. Lower level of curcumin and quercetin were evaluated by signal to noise ratio. The smallest concentration of analyte that yields an accurate response but cannot be quantified is known as the limit of detection (LOD). The smallest quantity of analyte that yields a correct response is known as the limit of quantitation (LOQ). The signal-to-noise ratio was used to calculate LOD and LOQ. The LOD value found for curcumin and quercetin were $0.041 \mu \mathrm{g} /$ and $0.0048 \mu \mathrm{g} / \mathrm{ml}$ respectively while LOQ value were found to be 0.082 and $0.039 \mu \mathrm{g} / \mathrm{ml}$ respectively. The LOD, LOQ, and calibration curve parameters are represented in Table 4.

\section{Robustness and ruggedness}

These include the ability to overcome adverse instrument, operator, and chromatographic circumstances such as flow rate, $\mathrm{pH}$, column temperature, and wavelength variations. Small purposeful adjustments in the wavelength were used to determine robustness. For analysis, the wavelength was first set to $254 \mathrm{~nm}$, but it was later altered to $221 \mathrm{~nm}$. Second, the flow rate was reduced from 0.7 to $0.5 \mathrm{ml} / \mathrm{min}$. The system's toughness

\begin{tabular}{|c|c|c|c|c|c|c|c|c|}
\hline Sr. No. & $\begin{array}{l}\text { \% drug } \\
\text { Added }\end{array}$ & $\begin{array}{c}\text { Amount of drug } \\
\text { added }\end{array}$ & Area & $\begin{array}{l}\text { Amount } \\
\text { Received }\end{array}$ & \% Recovery & Mean & $\%$ SD & $\%$ RSD \\
\hline \multirow{2}{*}{1} & \multirow{2}{*}{80} & \multirow{2}{*}{0.8} & 150.41 & 0.79 & 99.98 & \multirow{2}{*}{99.49} & \multirow{2}{*}{0.72} & \multirow{2}{*}{0.72} \\
\hline & & & 151.22 & 0.80 & 100 & & & \\
\hline \multirow{2}{*}{2} & \multirow{2}{*}{100} & \multirow{2}{*}{1.0} & 168.14 & 0.99 & 99.81 & \multirow{2}{*}{100.41} & \multirow{2}{*}{0.84} & \multirow{2}{*}{0.84} \\
\hline & & & 169.63 & 1.1 & 101.00 & & & \\
\hline \multirow{2}{*}{3} & \multirow{2}{*}{120} & \multirow{2}{*}{1.2} & 184.51 & 1.18 & 98.33 & \multirow{2}{*}{99.37} & \multirow{2}{*}{1.47} & \multirow{2}{*}{1.48} \\
\hline & & & 187.36 & 1.22 & 100.01 & & & \\
\hline
\end{tabular}

Table 4: The calibration curve parameters, limit of detection (LOD), limit of quantification (LOQ) for curcumin
and quercetin.
\begin{tabular}{|c|c|c|c|c|c|}
\hline Drug & $\begin{array}{c}\text { Calibration curve } \\
\text { equation }\end{array}$ & $\begin{array}{c}\text { Correlation coefficient }\left(\boldsymbol{R}^{2}\right) \\
\text { Linear range }(\boldsymbol{\mu g} / \mathrm{ml})\end{array}$ & $\begin{array}{c}\text { LOD } \\
(\mu \mathrm{g} / \mathrm{ml})\end{array}$ & $\begin{array}{c}\text { LOQ } \\
(\mu \mathrm{g} / \mathrm{ml})\end{array}$ \\
\hline Curcumin & $\mathrm{y}=78.983 \mathrm{x}+12.288$ & 0.9985 & $10-60$ & 0.041 & 0.082 \\
\hline Quercetin & $\mathrm{y}=60.839 \mathrm{x}-5.339$ & 0.9993 & $10-60$ & 0.0048 & 0.039 \\
\hline
\end{tabular}

\begin{tabular}{|c|c|c|c|c|c|c|}
\hline \multirow{2}{*}{ Method type } & \multicolumn{2}{|c|}{ Wavelength (nm) } & \multirow{2}{*}{ Conc. of sample $(\mu \mathrm{g} / \mathrm{ml})$} & \multirow{2}{*}{ Mean } & \multirow{2}{*}{$\%$ SD } & \multirow{2}{*}{$\%$ RSD } \\
\hline & Curcumin & Quercetin & & & & \\
\hline Developed Method & 254 & 254 & 2 & 476.34 & 5.73 & 1.20 \\
\hline Changed Method & 221 & 221 & 2 & 486.06 & 6.17 & 1.27 \\
\hline \multicolumn{7}{|c|}{ Flow Rate (ml/min) } \\
\hline Developed Method & 0.7 & 0.7 & 2 & 482.52 & 3.97 & 0.82 \\
\hline Changed Method & 0.5 & 0.5 & 2 & 429.97 & 3.80 & 0.88 \\
\hline \multicolumn{7}{|c|}{ Ruggedness } \\
\hline Operator 1 & 254 & 254 & 2 & 468.01 & 10.78 & 2.3 \\
\hline Operator 2 & 254 & 254 & 2 & 449.86 & 4.00 & 0.89 \\
\hline
\end{tabular}


Table 6: Pharmacokinetic parameters of Curcumin and Quercetin after intravenous administration of suspension in mice.

\begin{tabular}{|c|c|c|}
\hline $\begin{array}{c}\text { Pharmacokinetic } \\
\text { parameters }\end{array}$ & \multicolumn{2}{|c|}{ Results } \\
\hline & Curcumin & Quercetin \\
\hline $\mathrm{C}_{\max }(\mu \mathrm{g} / \mathrm{ml})$ & 7.534 & 8.899 \\
\hline $\mathrm{T}_{\max }(\mathrm{min})$ & 10 & 45 \\
\hline $\mathrm{AUC}_{0-\mathrm{t}}(\mu \mathrm{g} . \mathrm{min} / \mathrm{ml})$ & 61.434 & 131.433 \\
\hline
\end{tabular}

was tested by switching the operator. No, after altering the parameters, there were further changes. It denotes that the procedure has been tested. Table 5 depicts the robustness and roughness of curcumin and quercetin.

\section{Application of the developed method}

The above method was successfully applied for the pharmacokinetic studies of curcumin and quercetin in plasma of mice.

The Cmax, highest plasma drug concentration and $\mathrm{T}_{\max }$, the time of highest plasma drug concentration were found to be $7.534 \mu \mathrm{g} / \mathrm{ml}$ and $10 \mathrm{~min}$ for curcumin and The $\mathrm{C}_{\max }$, highest plasma drug concentration and $\mathrm{T}_{\max }$, the time of highest plasma drug concentration were found to be $8.899 \mu \mathrm{g} / \mathrm{ml}$ and $45 \mathrm{~min}$ for quercetin. Area under the curve $\left(\mathrm{AUC}_{0-t}\right)$ found to be $61.434 \mu \mathrm{g} . \mathrm{min} / \mathrm{ml}$ for curcumin and $131.433 \mu \mathrm{g}$. min / $\mathrm{ml}$ for quercetin. (Table 6).

\section{CONCLUSION}

For the simultaneous quantification of curcumin and quercetin, the RP-HPLC method reported here is accurate, sensitive, precise, and repeatable. It is cost effective method. It can be utilized for quality control analysis on a regular basis. of curcumin and quercetin in individual or in combination with other Phytophenols as per the regulatory guidelines. With the use of a $\mathrm{C}_{18}$ column, the established approach allows for good separation of curcumin and quercetin in bulk mixtures. Using a solvent system of methanol:0.05 percent orthophosphoric acid (80:20) at ambient temperature and a detection wavelength of $254 \mathrm{~nm}$, the flow rate was $0.7 \mathrm{ml} / \mathrm{min}$ with a run time of $15 \mathrm{~min}$. Curcumin elution took $5.25 \mathrm{~min}$ while quercetin took 8.78 min using the developed improved procedure. The developed method's system suitability parameters were investigated and determined to be within acceptable ranges. Curcumin's LOD and LOQ were reported to be 0.041 and $0.081 \mathrm{~g} / \mathrm{ml}$, respectively, while quercetin were 0.0048 and $0.039 \mathrm{~g} / \mathrm{ml}$, respectively. The linearity, precision, specificity, sensitivity, accuracy, raggedness, robustness, LOD, and LOQ of the devised method were all validated according to ICH recommendations. The results of the preceding observations show that the procedure is effective in both qualitative and quantitative analysis of the in the mixture. The developed method was successfully applied for estimation of pharmacokinetic parameters in swiss albino mice.

\section{ACKNOWLEDGEMENT}

The authors are thankful to the Principal, R. C. Patel Institute of Pharmaceutical Education and Research Shirpur, Maharashtra, India, for providing the necessary facilities to perform this research work.

\section{CONFLICT OF INTEREST}

The authors declare that there is no conflict of interest.

\section{ABBREVIATIONS}

RP-HPLC: Reverse Phase High Performance Liquid Chromatography; LOQ: Limit of Quantitation; LOD: Limit of Detection.

\section{Authors Contributions}

Ms. Nayana Patil: Laboratory work and manuscript drafting; Dr. Hitendra Mahajan: Concept building, data interpretation and final review.

\section{REFERENCES}

1. Sharma RA, Gescher AJ, Steward WP. Curcumin: The story so far. Eur J Cancer. 2005;41(13):1955-68. doi: 10.1016/j.ejca.2005.05.009, PMID 16081279.

2. Priyadarsini KI. The chemistry of curcumin: From extraction to therapeutic agent. Molecules. 2014;19(12):20091-112. doi: 10.3390/ molecules191220091, PMID 25470276.

3. Hatcher H, Planalp R, Cho J, Torti FM, Torti SV. Curcumin: From ancient medicine to current clinical trials. Cell Mol Life Sci. 2008;65(11):1631-52. doi: 10.1007/s00018-008-7452-4, PMID 18324353.

4. Borra SK, Gurumurthy P, Mahendra J. Antioxidant and free radical scavenging activity of curcumin determined by using different in vitro and ex vivo models. J Med Plants Res. 2013;7(36):2680-90.

5. Nelson KM, Dahlin JL, Bisson J, Graham J, Pauli GF, Walters MA. The essential medicinal chemistry of curcumin. J Med Chem. 2017;60(5):1620-37. doi: 10.1021/acs.jmedchem.6b00975, PMID 28074653.

6. Goel A, Kunnumakkara AB, Aggarwal BB. Curcumin as "Curecumin": from kitchen to clinic. Biochem Pharmacol. 2008;75(4):787-809. doi: 10.1016/j. bcp.2007.08.016, PMID 17900536.

7. Çıkrıkçı S, Mozioğlu E, Yılmaz H. Biological activity of curcuminoids isolated from Curcuma longa. Rec Nat Prod. 2008;2:19-24.

8. Yallapu MM, Jaggi M, Chauhan SC. Curcumin nanoformulations: A future nanomedicine for cancer. Drug Discov Today. 2012;17(1-2):71-80. doi: 10.1016/j.drudis.2011.09.009, PMID 21959306.

9. Prasad S, Tyagi AK, Aggarwal BB. Recent developments in delivery, bioavailability, absorption and metabolism of curcumin: the golden pigment from golden spice. Cancer Res Treat. 2014;46(1):2-18. doi: 10.4143/ crt.2014.46.1.2, PMID 24520218. 
10. Sari TP, Mann B, Kumar R, Singh RRB, Sharma R, Bhardwaj M, et al. Preparation and characterization of nanoemulsion encapsulating curcumin. Food Hydrocoll. 2015;43:540-6. doi: 10.1016/j.foodhyd.2014.07.011.

11. Li L, Zhang L, Du GH. Curcumin. Nat Small Molecule Drugs Plants. 2018:67984.

12. Gupta SC, Patchva S, Aggarwal BB. Therapeutic roles of curcumin: Lessons learned from clinical trials. AAPS J. 2013;15(1):195-218. doi: 10.1208/ s12248-012-9432-8, PMID 23143785.

13. Moghadamtousi SZ, Kadir HA, Hassandarvish P, Tajik H, Abubakar S, Zandi K. A review on antibacterial, antiviral, and antifungal activity of curcumin. BioMed Res Int. 2014;2014:186864. doi: 10.1155/2014/186864. PMID 24877064.

14. Chen LC, Chen YC, Su CY, Wong WP, Sheu MT, Ho HO. Development and characterization of lecithin-based self-assembling mixed polymeric micellar (saMPMs) drug delivery systems for curcumin [sci rep:37122]. Sci Rep. 2016;6:37122. doi: 10.1038/srep37122, PMID 27848996.

15. Aggarwal BB, Gupta SC, Sung B. Curcumin: An orally bioavailable blocker of TNF and other pro-inflammatory biomarkers. $\mathrm{Br} \mathrm{J}$ Pharmacol. 2013;169(8):1672-92. doi: 10.1111/bph.12131, PMID 23425071.

16. Lakhanpal P, Rai DK. Quercetin: A versatile flavonoid. Internet J Med Updat. Eng J. 2007;2(2).

17. Cai X, Fang Z, Dou J, Yu A, Zhai G. Bioavailability of quercetin: Problems and promises. Curr Med Chem. 2013;20(20):2572-82. doi: 10.2174/09298673113209990120, PMID 23514412.

18. Boots AW, Haenen GRMM, Bast A. Health effects of quercetin: From antioxidant to nutraceutical. Eur J Pharmacol. 2008;585(2-3):325-37. doi: 10.1016/j.ejphar.2008.03.008, PMID 18417116.

19. Perez-Vizcaino F, Duarte J, Jimenez R, Santos-Buelga C, Osuna A. Antihypertensive effects of the flavonoid quercetin. Pharmacol Rep. 2009;61(1):67-75. doi: 10.1016/s1734-1140(09)70008-8, PMID 19307694.

20. Gibellini L, Pinti M, Nasi M, Montagna JP, De Biasi S, Roat E, et al. Quercetin and cancer chemoprevention. Evid Based Complement Alternat Med. 2011;2011:591356. doi: 10.1093/ecam/neq053, PMID 21792362.

21. Li Y, Yao J, Han C, Yang J, Chaudhry MT, Wang S, et al. Quercetin, inflammation and immunity. Nutrients. 2016;8(3):167. doi: 10.3390/ nu8030167, PMID 26999194.

22. D'Andrea G. Quercetin: A flavonol with multifaceted therapeutic applications? Fitoterapia. 2015;106:256-71. doi: 10.1016/j.fitote.2015.09.018, PMID 26393898.

23. Formica JV, Regelson W. Review of the biology of quercetin and related bioflavonoids. Food Chem Toxicol. 1995;33(12):1061-80. doi: 10.1016/02786915(95)00077-1, PMID 8847003.

24. Edwards RL, Lyon T, Litwin SE, Rabovsky A, Symons JD, Jalili T. Quercetin reduces blood pressure in hypertensive subjects. J Nutr. 2007;137(11):2405-11. doi: 10.1093/jn/137.11.2405, PMID 17951477.

25. Murota K, Terao J. Antioxidative flavonoid quercetin: Implication of its intestinal absorption and metabolism. Arch Biochem Biophys. 2003;417(1):12-7. doi: 10.1016/s0003-9861(03)00284-4, PMID 12921774.

26. Lesjak M, Beara I, Simin N, Pintać D, Majkić T, Bekvalac K, et al. Antioxidant and anti-inflammatory activities of quercetin and its derivatives. J Funct Foods. 2018;40:68-75. doi: 10.1016/j.jff.2017.10.047.

27. Russo M, Spagnuolo C, Tedesco I, Bilotto S, Russo GL. The flavonoid quercetin in disease prevention and therapy: facts and fancies. Biochem Pharmacol. 2012;83(1):6-15. doi: 10.1016/j.bcp.2011.08.010, PMID 21856292.

28. Li L, Zhang L, Du GH. Quercetin. Nat Small Molecule Drugs Plants. 2018:72530.
29. Kadam PV, Bhingare CL, Nikam RY, Pawar SA. Development and validation of UV spectrophotometric method for the estimation of curcumin in cream formulation. Pharm Methods. 2013;4(2):43-5. doi: 10.1016/j. phme.2013.08.002.

30. Patil SJ, Salunkhe VR. Simultaneous estimation of curcumin and quercetin in Ayurvedic Proprietary medicine by U.V. spectrophotometry. Int J Res Ayurveda Pharm. 2012;3(2):267-71.

31. Patil V, Angadi S, Devdhe S. Determination of quercetin by UV spectroscopy as quality control parameter in herbal plant: Cocculus hirsutus. J Chem Pharm Res. 2015;7(1):99-104.

32. Laila O, Murtaza I, Abdin MZ, Ahmad S, Ganai NA, Jehangir M. Development and Validation of HPTLC Method for Simultaneous Estimation of diosgenin and quercetin in Fenugreek Seeds (Trigonella foenum-graceum). ISRN Chromatogr. 2014;2014:1-8. doi: 10.1155/2014/583047.

33. Sajeeth $\mathrm{Cl}$, Manna PK, Manavalan R, Jolly Cl. Quantitative estimation of gallic acid, Rutin and quercetin in certain herbal plants by HPTLC method. Chem Sin. 2010;1(2):80-5.

34. Himesh S, Sita Sharan P, Govind N, Soni H, Professor A. Qualitative and quantitative profile of curcumin from ethanolic extract of Curcuma longa. Irjp. 2011;2(4):180-4.

35. Sehgal S, Gupta V, Gupta R, Saraf SA. Quantitative estimation of quercetin in Mimusops elengi L. (Bakul) leaves by HPTLC. Pharm Lett. 2011;3(5):12-9.

36. Ashok Kumar BS, Satish KV, Suresh N, Sheshadri Sekhar D, Narayan Swamy VB. Estimation of rutin and quercetin in Amarnathus spinosus by HPLC. Asian J Chem. 2008;20(2):1633-5.

37. Kaushal GP, Sekhon BS, Bhatia IS. Spectrophotometric determination of quercetin with $\mathrm{VO}_{2}+$. Mikrochim Acta. 1979;71(5-6):365-70. doi: 10.1007/ BF01197407.

38. Shaikh S, Jain V. Development and validation of a RP-HPLC method for the simultaneous determination of quercetin, ellagic acid and rutin in hydroalcoholic extract of triphala churna. Int J Appl Pharm. 2018;10(3):169-74.

39. Lakka NS, Goswami N, Balakrishna P. Development and validation of a RP-HPLC for simultaneous determination of ibuprofen and paracetamol in solid dosage forms: Application to dissolution studies. Int J Res Pharm Sci. 2011;2(3):331-7.

40. Davoodvandi A, Sahebnasagh R, Mardanshah O, Asemi Z, Nejati M, Shahrzad MK, et al. Medicinal Plants As Natural Polarizers of Macrophages: Phytochemicals and Pharmacological Effects. Curr Pharm Des;25(30):3225-38. doi: 10.2174/1381612825666190829154934.

41. Sanphui P, Goud NR, Khandavilli UBR, Nangia A. Fast Dissolving Curcumin Cocrystals. Cryst Growth Des. 2011;11(9):4135-45. doi: 10.1021/cg200704s.

42. Nafiz C. HPLC determination OF Cefprozil in tablets with monolithic and $\mathrm{C}_{18}$ silica column. J Sep Sci. 2011;34:2223-31. doi: 10.1002/jssc.201100170.

43. Amirhosseoin D, Roxana S, Omid M, Zotallah A, Medicinal plants as natural polarizer of macrophages: Phytochemicals and pharmacological effects, Current pharmaceutical design. 2019;(25):1-14.doi: https://doi.org/10.2174/1 381612825666190829154934.

44. Maria A, Roderick E, Wasylishen M, Bernard V, Terskish B, Vladimir M, Capturing elusive polymorphs of curcumin : A structural characterization and computational study. Crystal Growth and Design. 2011;9:4135-45. https://doi. org/10.1021/cg200704s.

45. Nafiz C, HPLC determination OF Cefprozil in tablets with monolithic and c18 silica column. Journal of Separation Science. 2011;34:2223-31 https://doi. org/10.1002/jssc.201100170. 
PICTORIAL ABSTRACT

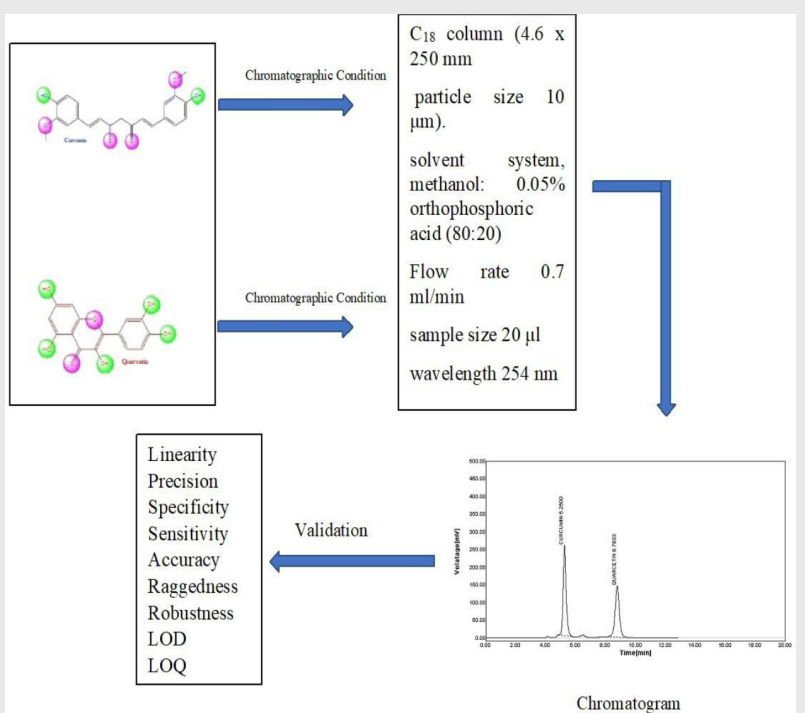

\section{SUMMARY}

RP-HPLC method for simultaneous estimation of Curcumin and Quercetin was developed. The developed method enables the excellent separation of curcumin and quercetin in bulk mixture. The cleared resolution of two phytochemicals was obtained. The final chromatographic conditions are validated to establish accuracy, precision, LOD and LOQ of the method. Developed analytical method successfully employed for estimation of pharmacokinetic parameters

Cite this article: Patil N, Mahajan H. Development and Validation of RP-HPLC Method for Simultaneous Qualitative and Quantitative Estimation of Curcumin and Quercetin in Bulk Mixture. Indian $\mathrm{J}$ of Pharmaceutical Education and Research. 2022;56(1):247-54. 